\title{
Cultivable Sponge-Associated Actinobacteria from Coastal Area of Eastern Mediterranean Sea
}

\author{
Özlem Öner'1, Güner Ekiz², E. Esin Hameş²*, Volkan Demir³, Özkan Gübe1, \\ F. Can Özkaya ${ }^{1}$, M. Baki Yokeş ${ }^{4}$, Ataç Uzel ${ }^{5}$, Erdal Bedir ${ }^{2 *}$ \\ ${ }^{1}$ Department of Biotechnology, Graduate School of Natural and Applied Sciences, Ege University, \\ Bornova, Izmir, Turkey \\ ${ }^{2}$ Department of Bioengineering, Faculty of Engineering, Ege University, Bornova, Izmir, Turkey \\ ${ }^{3}$ Institute of Marine Sciences and Management, İstanbul University, Vefa, İstanbul, Turkey \\ ${ }^{4}$ Department of Molecular Biology and Genetics, Faculty of Arts and Sciences, Haliç University, Sıracevizler Cd. \\ No: 29 Bomonti, Şişli, Istanbul, Turkey \\ ${ }^{5}$ Department of Biology, Faculty of Science, Ege University, Bornova, Izmir, Turkey \\ Email: ${ }^{*}$ esin.kocabas@ege.edu.tr, ${ }^{*}$ erdal.bedir@ege.edu.tr
}

Received 21 February 2014; revised 18 April 2014; accepted 30 March 2014

Copyright (C) 2014 by authors and Scientific Research Publishing Inc.

This work is licensed under the Creative Commons Attribution International License (CC BY).

http://creativecommons.org/licenses/by/4.0/

(c) (i) Open Access

\begin{abstract}
In this study, 16 marine sponge samples collected from Eastern Mediterranean Sea were used for the isolation of sponge-associated Actinobacteria. Different media and pre-treatment methods were applied for the isolation experiments. In total, 7578 actinomycetes colonies were observed on the primary isolation plates, and 20 representative isolates were selected for further studies based on their morphologies and chemical profiles. These isolates were investigated for their antimicrobial activities, seawater requirements and $16 \mathrm{~S}$ rRNA gene sequences. The phylogenetic analysis revealed that $80 \%$ of the isolated Actinobacteria was a member of the Streptomyces genus. All the isolates showed no absolute requirement for seawater. Fifteen of the selected isolates exhibited antimicrobial activity against methicillin resistant Staphylococcus aureus and vancomycin resistant Enterococcus faecium, whereas 3 isolates were active against Candida albicans.
\end{abstract}

\section{Keywords}

Sponge-Associated Actinobacteria, Streptomyces, Nocardiopsis, Antimicrobial Activity

*Corresponding authors. 


\section{Introduction}

Sponges (Phylum Porifera) are simple, multicellular and filter feeding sessile invertebrates attached to solid surfaces in benthic habitats. More than 6000 described species of sponges inhabit a wide variety of marine and fresh water environment [1] [2]. Their importance increased with the discovery that they are significant sources of marine bioactive compounds accounting for up to $40 \%$ of all known natural marine products [3]. Several studies were performed to extract sponge metabolites that they use for their own defence against particular types of microorganisms [2] [4] [5]. On the other hand, the production of a wide variety of secondary metabolites by sponge-associated actinobacteria is well known [2]. It is proposed that in some cases sponge-associated bacteria are the actual producers of bioactive compounds of sponge-derived products [6]-[8]. The biomass of sponge comprises significant percentage (up to 60\%) of bacteria that are located in sponge cells and sponge matrix [9]. Both culture-depend and molecular studies demonstrated that actinobacteria are significant microbial associates within marine sponges [10]-[13].

Actinobacteria are Gram positive, mostly aerobic, mycelial and primarily soil organisms, gathering attention as significant producers of therapeutics. However, recent studies revealed that some Actinobacteria taxa are natural or well-adapted inhabitants of marine environments. These bacteria are quite interesting because of their great potential in extracellular enzyme production, as well as in the synthesis of a large variety of bioactive metabolites. Antibiotic-producing microorganisms are comprised of roughly $70 \%$ actinobacteria [14]. Streptomyces is the dominant source of these antibiotics among the other genera of Actinobacteria [15]. Moran et al. (1995) [16], using 16S rRNA probes, reported that the first indigenous Streptomyces populations were a part of the marine bacterial community. Mincer et al. (2002) [17] were also reported for the first time the widespread distribution and persistent actinobacteria occurrence in the marine environment.

Studies on sponge-associated Actinobacteria are limited to a few sponges [3]. Culture-independent studies within the sponges Rhopaloeides odorabile [10], Xestospongia spp. [9], Aplysinaa erophoba, Theonella swinhoei [11] and culture-dependent studies within the sponges Pseudoceratina clavata [18], Xestospongia spp. [9], Craniella australiensis [19], Hymeniacidon perleve [3], Haliclona sp. [20], Iotrochota sp. [21], Halichondri apanicea [22], Stelletta tenuis and Halichondria rugosa [23] have shown the existence of sponge-associated actinobacteria. However these studies are insufficient to provide a general understanding of their diversity, distribution and ecology [3].

The aim of this study is to determine both the diversity of cultivable sponge-associated actinobacteria from various marine sponge species collected from Eastern Mediterranean Sea and their antimicrobial activities against the significant and/or antibiotic resistant pathogens.

\section{Material and Methods}

\subsection{Sponge Samples}

In this study, 16 marine sponges belonging to 11 genera were collected by SCUBA diving at depths of 2 - $19 \mathrm{~m}$ on the Eastern Mediterranean coast of Turkey in May 2011. Three different locations were chosen for sampling area; Beşparmak Island, Dana Island and Akkuyu Bay (Taşucu-Mersin, Turkey) (Table 1). The sponges were transferred to sterile $500 \mathrm{ml}$ polypropylene bottles containing seawater, and kept on ice until preliminary processing.

\subsection{Sample Processing, Isolation and Enumeration of Culturable Actinobacteria}

The sponge specimens were rinsed five times with sterile aged seawater to remove loosely attached microorganisms prior to cultivation. The sponges were cut into small pieces $\left(\right.$ ca. $1 \mathrm{~cm}^{3}$ ) using a sterile scalpel in order to isolate actinobacteria from the inner surface of the samples, and then homogenised in 10 volumes of sterile seawater using a blender [18] [23]-[25]. Different pre-treatment methods were used prior to inoculation.

Method A: The supernatant of the homogenised sponges was diluted in tenfold series $\left(10^{-1}, 10^{-2}, 10^{-3}\right.$ and $\left.10^{-4}\right)$ with sterile seawater and inoculated $(100 \mu \mathrm{l}$ and $200 \mu \mathrm{l})$ with dilution of $10^{-1}, 10^{-2}$ for sponge extract agar (SE) and water agar (AW) plates, and with dilution of $10^{-3}-10^{-4}$ for M1, M6, R2A and Actinomycete isolation agar (AIA) plates in duplicate (Table 2).

Method B: The supernatant of the homogenised sponges was diluted $\left(10^{-1}\right.$ and $\left.10^{-2}\right)$ with sterile salt solution $\left(6 \% \mathrm{NaCl}\right.$ ) and heated up to $55^{\circ} \mathrm{C}$ for 6 min prior to inoculation. 100, 200 and $300 \mu \mathrm{l}$ volumes were used for inoculation onto ISP4 agar (supplemented with $\mathrm{NaCl}$ ) plates in triplicate. 
Table 1. Sponges and sampling sites.

\begin{tabular}{|c|c|c|c|}
\hline Sponge code & Marine sponges & Sampling location & Depth (m) \\
\hline $8-1$ & Ircinia variabilis & \multirow{8}{*}{$\begin{array}{c}\text { Beşparmak Island } \\
\left(36^{\circ} 07^{\prime} 19,26^{\prime \prime} \mathrm{N} ; 33^{\circ} 31^{\prime} 50,14^{\prime \prime} \mathrm{E}\right)\end{array}$} & 29 \\
\hline $8-2$ & Petrosia ficiformis & & 18.4 \\
\hline $8-3$ & Axinella damicornis & & 19.9 \\
\hline $8-4$ & Dysidea avara & & 22.5 \\
\hline $8-5$ & Agelas oroides & & 21 \\
\hline $8-6$ & Sarcotragus spinosulus & & 21 \\
\hline $8-7$ & Ircinia sp. & & 8 \\
\hline $8-8$ & Chondrosia reniformis & & 15.7 \\
\hline $9-1$ & Sarcotragus fasciculatus & \multirow{6}{*}{$\begin{array}{c}\text { Akkuyu Bay, } \\
\left(36^{\circ} 14^{\prime} 08,87^{\prime \prime} \mathrm{N} ; 33^{\circ} 53^{\prime} 94,00^{\prime \prime} \text { E) }\right.\end{array}$} & 13 \\
\hline $9-2$ & Phorbas fictitius & & 12.9 \\
\hline $9-3$ & Axinella polypoides & & 12.3 \\
\hline $9-4$ & Spirastrella cunctatrix & & 11.3 \\
\hline $9-5$ & Axinella damicornis & & 12.3 \\
\hline $9-6$ & Sarcotragus fasciculatus & & 7 \\
\hline $10-1$ & Chondrilla nucula & \multirow{2}{*}{$\begin{array}{c}\text { Dana Island, } \\
\left(36^{\circ} 11^{\prime} 53,97^{\prime \prime} \mathrm{N} ; 33^{\circ} 46^{\prime 2} 20,84 " \mathrm{E}\right)\end{array}$} & 2 \\
\hline $10-2$ & Oscarella lobularis & & 5 \\
\hline
\end{tabular}

Table 2. Composition of the 8 different media for the isolation of actinomycetes from marine sponge samples.

\begin{tabular}{|c|c|c|}
\hline Media & Ingredients & Reference \\
\hline M1 & $\begin{array}{l}\text { Starch, } 10 \text { g; yeast extract, } 4 \text { g; peptone, } 2 \text { g; agar, } 18 \text { g and 1L of natural } \\
\text { seawater }\end{array}$ & {$[3][17][25]$} \\
\hline M6 & $\begin{array}{l}\text { Beef extract, } 4 \text { g; peptone, } 4 \text { g; yeast extract, 1; glucose, } 10 \text { g; NaCl, } 20 \text { g; } \\
\text { agar, } 20 \text { g and 1L of distilled water }\end{array}$ & {$[10]$} \\
\hline $\mathrm{R} 2 \mathrm{~A}$ & $\begin{array}{l}\text { Yeast extract, } 0.5 \text { g; glucose, } 0.5 \text { g; peptone, } 0.5 \text { g; casein hydrolysate, } 0.5 \text { g; } \\
\text { starch, } 0.5 \text { g; sodium pyruvate, } 0.3 \text { g; } \mathrm{K}_{2} \mathrm{HPO}_{4} 0.3 \text { g; } \mathrm{MgSO}_{4} \cdot 7 \mathrm{H}_{2} \mathrm{O}, 0.05 \text { g; } \\
\text { agar, } 18 \text { g; } 1 \mathrm{~L} \text { of seawater and distilled water (2:2) (Becton Dickinson) }\end{array}$ & [9] \\
\hline $\begin{array}{l}\text { Actinomycete isolation agar } \\
\text { (AIA) }\end{array}$ & $\begin{array}{l}\text { Sodium caseinate, } 2 \mathrm{~g} \text {; L-asparagine, } 0.1 \mathrm{~g} \text {; sodium propionate, } 4 \mathrm{~g} ; \mathrm{K}_{2} \mathrm{HPO}_{4} \text {, } \\
0.5 \mathrm{~g} ; \mathrm{MgSO}_{4} \cdot 7 \mathrm{H}_{2} \mathrm{O} 0.2 \mathrm{~g} \text {, ferrous sulphate } 0.001 \text { g, glycerol, } 5 \text { g; agar } 15 \text { g; } \\
1 \mathrm{~L} \text { of seawater and distilled water (2:2) (Becton Dickinson) }\end{array}$ & [9] \\
\hline SE Medium (sponge extract) & $\begin{array}{l}\text { Sponge extract, } 10 \mathrm{ml} \text {; agar, } 15 \mathrm{~g}, 1 \mathrm{~L} \text { of seawater and distilled water }(50 \%) \text {. } \\
\text { The water extract of sponge was prepared by grinding } 20 \mathrm{~g} \text { tissue in } 200 \mathrm{ml} \\
\text { sterile seawater and sterilized by filtration through a } 0.2 \mu \mathrm{m} \text { pore size filter }\end{array}$ & {$[35]$} \\
\hline AW Medium (agar water) & Agar, 15 g; 1L of seawater & {$[26][40]$} \\
\hline ISP4 (with 6\% NaCl) & $\begin{array}{l}\text { Starch, } 10 \mathrm{~g}, \mathrm{~K}_{2} \mathrm{HPO}_{4}, 1 \mathrm{~g} ; \mathrm{MgSO}_{4} \cdot 7 \mathrm{H}_{2} \mathrm{O}, 1 \mathrm{~g} ; \mathrm{NaCl}, 60 \mathrm{~g} ;\left(\mathrm{NH}_{4}\right)_{2} \mathrm{SO}_{4}, 2 \mathrm{~g} \text {; } \\
\mathrm{CaCO}_{3}, 2 \text { g; trace salt solution } 1 \mathrm{ml} \text {; agar } 20 \mathrm{~g} \text {, } 1 \mathrm{~L} \text { of distilled water. }\end{array}$ & {$[41]$} \\
\hline $\begin{array}{l}\text { SMP (sponge mannitol } \\
\text { peptone) }\end{array}$ & $\begin{array}{l}\text { Mannitol } 500 \mathrm{mg} \text {, peptone } 100 \mathrm{mg}, 10 \% \text { sponge extract and rifampicin } \\
(5 \mu \mathrm{g} / \mathrm{ml}) \text { and } 1 \mathrm{~L} \text { of seawater and distilled water (50\%) }\end{array}$ & $\begin{array}{l}\text { Modified form Jensen } \\
\text { et al., } 2005 \text { [26] }\end{array}$ \\
\hline
\end{tabular}

Method C: The supernatant of the homogenised sponges was diluted to $10^{-2}$ with sterile seawater (50\%) and heated up to $55^{\circ} \mathrm{C}$ for 6 min prior to inoculation. $100 \mu$ l volume was spread onto M1 and R2A media in duplicate (Table 2) [26].

Method D: In this experiment, inoculations were implemented using 96 well microplates containing $180 \mu \mathrm{l}$ media. Three different broth media were used, one of which was a poor nutritional medium designated as sponge mannitol peptone (SMP), and the other two were rich nutritional media as M1 and R2A (prepared without agar) (Table 2). Total bacterial cells were determined in the supernatant of the homogenised sponges with DAPI (4', 6-diamidino-2-phenylindole) using fluorescence microscopy. The nutrient rich and poor media were inoculated with 1 - $5 \mathrm{cfu} / \mathrm{ml}$ and $10-100 \mathrm{cfu} / \mathrm{ml}$, (cfu: colony forming unit) respectively. Inoculated microplates were incubated at room temperature $\left(26^{\circ} \mathrm{C}\right)$ and monitored $6-8$ weeks visually and with the aid of a stereo mi- 
croscope. Bacteria that formed visible mycelia were picked and transferred onto new agar plates (M1 medium), and also $5 \mu \mathrm{l}$ aliquots from each well were transferred onto M1 agar plates after 8 weeks [27].

Eight different nutrient rich and poor media were used for the isolation experiments. All media were supplemented with cycloheximide $(100 \mu \mathrm{g} / \mathrm{ml})$ and nalidixic acid $(25 \mu \mathrm{g} / \mathrm{ml})$ to prevent the growth of fungi and Gram negative bacteria, respectively. In all cases, two plates were prepared for each dilution and each medium. Actinobacteria counts were calculated as the mean number of cfu.

\subsection{Cultivation and Extraction of Secondary Metabolites}

All cultivation processes were implemented in $250 \mathrm{ml}$ Erlenmeyer flasks with $50 \mathrm{ml} \mathrm{M} 1$ medium, at $28^{\circ} \mathrm{C}$ and $150 \mathrm{rpm}$ for 7 - 12 days depending on their growth rate. Each culture was inoculated separately with a $1 \mathrm{~cm}^{2}$ piece of culture grown on M1 agar plate for 2 weeks at $28^{\circ} \mathrm{C}$. Mycelial biomass was removed from the culture filtrate by centrifugation at $7000 \mathrm{rpm}$ for $5 \mathrm{~min}$ after incubation period, and cell-free supernatant was extracted with ethyl acetate (EtOAc) $(1: 1)$. The EtOAc was then evaporated under vacuum $\left(<35^{\circ} \mathrm{C}\right)$ to obtain crude extract.

\subsection{Selection of Representative Isolates}

The selection of the representative isolates was carried out based on chemical profiles derived from thin layer chromatography (TLC) experiments. The extracts were spotted onto silica gel plates, at a distance of $1 \mathrm{~cm}$ from the bottom, and then allowed to dry at room temperature. Then the plates were placed in pre-saturated TLC chamber, containing chloroform: methanol (90:10) solvent system as mobile phase. The plates were removed from the TLC chamber after development. All the plates were visualized under ultraviolet (UV) light (254 and $365 \mathrm{~nm}$ ), and the spots were marked. Thus the isolates were basically grouped according to their chemical profiles to reduce further efforts towards bioactive metabolites. In the meantime, isolates were evaluated for pigment production during cultivation on M1 agar. Therefore the presence of pigmentations was another criterion for the selection of represented isolates.

\subsection{Antimicrobial Activity of Culture Extracts of Isolates}

Disc diffusion assay was performed according to Clinical and Laboratory Standards [28] for the determination of antimicrobial activity. Methicillin-resistant Staphylococcus aureus (ATCC 43300) (MRSA), vancomycin-resistant Enterococcus faecium (DSM 13590) (VREF), enteropathogenic Escherichia coli O157:H7 (RSKK 234), Pseudomonas aeruginosa (ATCC 27853) and Candida albicans (DSM 5817) (antifungal activity test strain) were used as test microorganisms. Pathogen suspensions which were adjusted to 0.5 Mc Farland turbidimetric standards were inoculated to Mueller Hinton agar (MHA) and Saboraud dextrose agar (SDA) for bacteria and yeast, respectively. Sterile paper disks $(6 \mathrm{~mm})$ loaded with the extracts $(30 \mu \mathrm{l})$ were placed onto the surface of agar plates, previously inoculated with the test organisms. Plates were incubated at $37^{\circ} \mathrm{C}$ for $24 \mathrm{~h}$ for bacterial cultures, and at $30^{\circ} \mathrm{C}$ for $48 \mathrm{~h}$ for the yeast. The antimicrobial activity was determined as inhibition zone after incubation period. Gentamicin sulphate and nystatin were used as standard compounds for antimicrobial experiments.

\subsection{DNA Extraction and PCR Amplification}

The isolates, demonstrating different TLC patterns, growth characteristics and pigmentation, were chosen for 16S rRNA gene sequence analysis. The total genomic DNA was extracted from the isolates as described by Liu et al. (2000) [29]. The success of the genomic DNA extraction was confirmed by gel electrophoresis (1\%) for integrity and quantity. Polymerase chain reaction (PCR) was implemented to amplification of 16S rRNA gene using universal primers 27F (5'-AGAGTTTGATCCTGGCTCAG-3') and 1492R (5'-GGTTACCTTGTTACGACTT-3'). PCR programme was initial denaturing cycle at $94^{\circ} \mathrm{C}$ for 5 min, and 30 amplification cycle (denaturing; $94^{\circ} \mathrm{C}$ for $45 \mathrm{~s}$, primer annealing; $50^{\circ} \mathrm{C}$ for $45 \mathrm{~s}$, primer extending; $72^{\circ} \mathrm{C}$ for $45 \mathrm{~s}$ ).

\subsection{DNA Sequencing and Analysing}

Purification of PCR products was done by using a Macherey-Nagel PCR extraction kit according to the manufacturer's instructions. Sequencing reaction was carried out with the BigDye Terminator v3.1 Cycle sequencing 
kit (Applied Biosystems), and it was analysed with an ABI PRISM 3100 Genetic Analyser (Applied Biosystems) as specified by the manufacturer. Primers used for sequencing were 27F and 1492R. A BLAST search of the National Center for Biotechnology Information (NCBI) (http://www.ncbi.nlm.nih.gov/) was performed to identify the nearest neighbour to the amplified sequence. The sequences were aligned to create a matrix using CLUSTAL W. The tree topologies were evaluated by bootstrap analyses on 1000 replications and phylogenetic tree were inferred using the neighbour-joining method. The 16S rDNA sequences of the isolates were deposited to GenBank under accession numbers JX091003 to JX091022.

\subsection{Sea Water Requirement}

All media used for the isolation of actinobacteria contained sea water or $\mathrm{NaCl}$. The isolates were inoculated separately onto the surface of M1 agar prepared with seawater and distilled water. Growth was monitored on the plates visually up to 3 weeks for the determination of seawater requirement for growth.

\section{Results}

\subsection{Sponges}

Eight sponge species collected from Beşparmak Island were identified as Ircinia variabilis (Schmidt, 1862) (Figure 1), Petrosia (Petrosia) ficiformis (Poiret, 1789), Axinella damicornis (Esper, 1794), Dyside aavara (Schmidt, 1862), Agelas oroides (Schmidt, 1864), Sarcotragus spinosulus (Figure 1), Ircinia sp. and Chondrosia reniformis (Nardo, 1847). Two sponge species from Dana Island were determined as Chondrilla nucula (Schmidt, 1862) and Oscarella lobularis (Schmidt, 1862), whereas six samples from Akkuyu Bay were authenticated as Sarcotragus fasciculatus (Pallas, 1766), Phorbas fictitious (Bowerbank, 1866) (Figure 1), Axinella polypoides (Schmidt, 1862), Spirastrella cunctatrix (Schmidt, 1868) and Axinella damicornis.

\subsection{Isolation and Selection of Cultivable Sponge-Associated Actinobacteria}

A total of 16 sponge samples were inoculated onto 592 primary isolation plates for the implementation of all methods. A total of 7578 typical actinomycetes colonies were observed on the plates. Representatives of all actinomycetes morphotypes (based on the colony morphology on different media) were obtained from primary isolation plates, and 88 of the colonies were subsequently transferred onto the new media until reaching pure cultures. All isolates were deposited in Actinomycetes Culture Collection (ACTINOCC) registered to World Federation of Culture Collections No. 952 as sponge-associated actinobacteria.

The highest total colony forming unit of actinomycete was obtained from Axinella damicornis (sample 9-5) (2178 cfu) followed by Ircinia sp. (sample 8-7) (1437 cfu). Four different methods and 6 different media were used for isolation experiments. In these methods M1 is a well-defined medium for the isolation of actinobacteria [3] [17]. In method B, performing salt plus heat pre-treatment, only four sponge samples (sample 8-6, 8-7, 8-8 and 10-2) provided the isolation of actinobacteria with limited number. SE agar plates gave low number of actinobacteria colonies whereas AW agar plates have not. Additionally any actinomycetes colony was not isolated

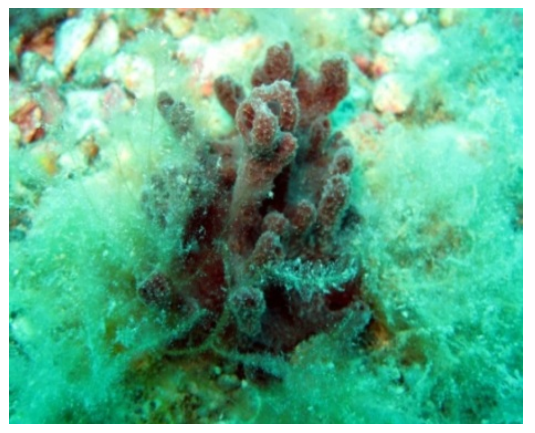

(a)

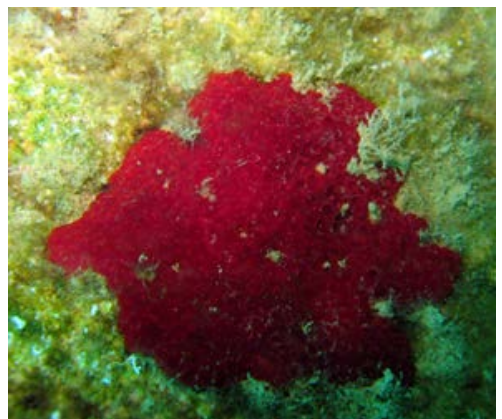

(b)

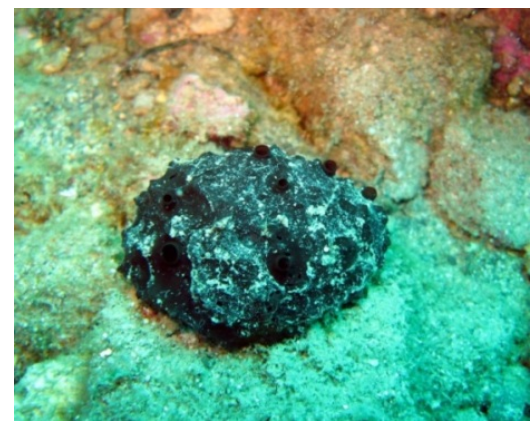

(c)

Figure 1. In situ photographs of the external morphology, distinct coloration and growth forms of three sponge species. a) Ircinia variabilis, b) Phorbas fictitious c) Sarcotragus spinosulus. 
from the sponge Spirastrella cunctatrix (Sample 9-4) (Table 3).

Most of the isolated colonies (88) exhibited diffusible orange pigmentations on M1 agar plate (from bright to pale orange). The extracts obtained from these isolates displayed almost identical TLC profiles, and afforded high antimicrobial activity versus the pathogens. Eight of the 20 representative isolates were obtained from method A, 5 isolates from method B, 1 isolate from method C and 7 isolates from method D.

\subsection{Phylogenetic Analysis Based on 16S rRNA Gene Sequences}

The 16S rRNA genes of the 20 representative isolates were sequenced. A BLAST analysis was carried out via blastn search through GenBank, revealing that 16 of the isolates were members of the genus Streptomyces. Four isolates were found to be members of Nocardiopsis. Figure 2 shows the phylogenetic relationship among the isolates together with the type strains of Actinobacteria as reference.

The 16S rRNA gene sequence of isolates 8SM39, 8SM44, 8SM48 and 8SM50 shares 99\% homology with that of Nocardiopsis alba (Figure 2). Three of all (8SM39, 8SM44, 8SM48) isolated from ISP4 (supplemented with $6 \% \mathrm{NaCl}$ ) agar plates also exhibited salt tolerance.

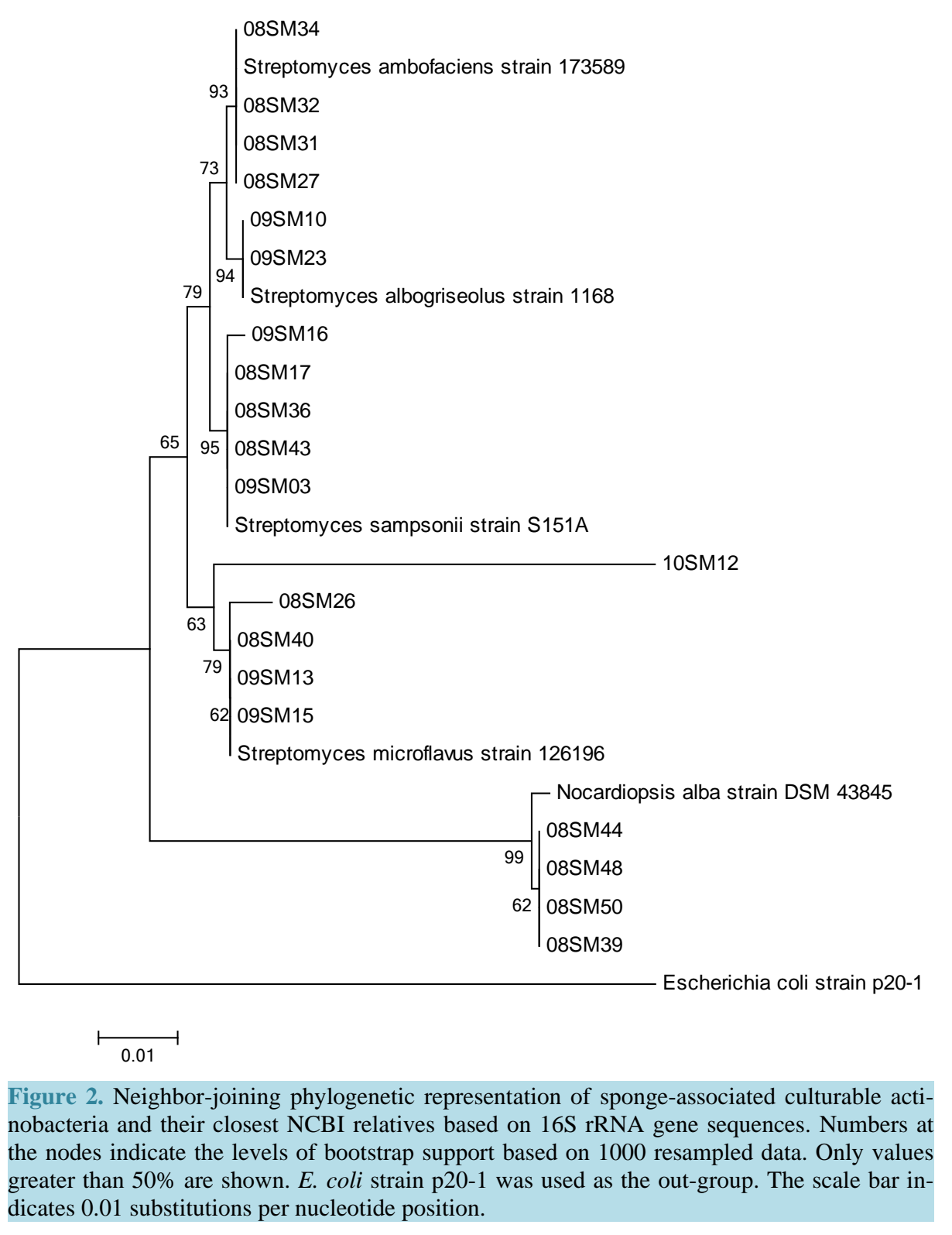




\subsection{Antimicrobial Activity of Representative Isolates}

Extracts of the fermentation broths were used for antibacterial and antifungal activity against the pathogens including antibiotic resistant MRSA, and VREF, $P$. aeruginosa, $E$. coli and yeast $C$. albicans using the disc diffusion method. Of the 20 isolates tested, 16 produced antimicrobial metabolites inhibiting at least one of the test pathogens. Fifteen isolates inhibited the growth of antibiotic resistant MRSA and/or VREF, whereas 3 isolates were also active against $C$. albicans. Gram-negative test microorganisms $E$. coli and $P$. aeruginosa were not susceptible to the extracts. The antimicrobial activity of the isolates is presented in Table 4.

\subsection{Sea Water Requirement}

All of the isolates recovered in this study can grow on media prepared with seawater. However around $61 \%$ of the isolates grew considerably faster and showed abundant sporulation in media containing seawater. In addition, $39 \%$ of the isolates did not show any clear preference for media with or without seawater (Table 4).

\section{Discussion}

Method A is a classical approach for the isolation of actinobacteria from marine sponge samples [18] [23] [25] [30]. In general, the M1, M6, R2A and AIA agar plates, which are nutrient rich media, afforded the highest numbers of actinobacteria within the method A. M1 and R2A media were used in method A (without heat pre-treatment) and method $\mathrm{C}$, and the results of these two experiments clearly indicated positive effect of the heat pre-treatment for the isolation rate of actinobacteria (Table 3). The purpose of the heat process is to reduce the number of unicellular bacteria in favour of actinobacteria [31], and this strategy has been used successfully for the isolation of marine actinobacteria frequently [17] [18] [26] [31]. Selective isolation method using $\mathrm{NaCl}$ tolerance was used in method B combined with heat treatment. Actinomycetes from marine environment show good growth in the presence of $\mathrm{NaCl}$ [17] [31]. Members of Nocardiopsis genus have been frequently isolated from areas with high salt concentration [32]. Present study, three quarters of Nocardiopsis isolates were obtained from method $\mathrm{B}$ using $\mathrm{NaCl}$ and heat for selective isolation.

The existences of sponge-associated actinobacteria from the 16 sponge samples were variable. Among the samples, Spirastrella cunctatrix (9-4) did not give the colony of actinobacteria on the isolation plates (Table 3). This may be related to the morphological structure of the sponge that covers the rocky surface as a thin cloth (Figure 1).

Taking our preliminary studies into consideration, we readily deduced the presence of actinomycin-type metabolites in fermentation broth extracts. Consequently, 88 isolates were lessened to 20 in terms of TLC profile, colonial appearance and pigmentation. The selected isolates were from 8 different sponge species, while no representative isolate was chosen from Ircinia variabilis (sample 8-1), Sarcotragus fasciculatus (sample 9-6), Petrosia ficiformis (sample 8-2) and Chondrilla nucula (sample 10-1). The existence, abundance and diversity of the cultivable actinobacteria vary significantly among sponge species [23]. However, Micromonospora, Rhodococcus and Streptomyces were reported as dominant groups in marine environments [33].

During the last decade, innovative cultivation strategies were developed to increase the isolation efficiency of new microorganisms from the marine environment. In these methods bacteria are separated and incubated individually and/or nutrient poor media are used as growth media. Thus, the repression of slow-growing strains due to fast-growing bacteria can be avoided and nutrient poor media better mimic the nutrient concentrations found in natural environments. The bacteria that need lower nutrient concentration and longer incubation times have a chance to grow [27] [30]. In the current study, traditional isolation techniques together with modified ones were used for the isolation of actinobacteria. Considering newly established approaches, the sponge extracts, diluted to very small numbers of bacteria ranging from 1 to 10 cells per well, were inoculated by using method $\mathrm{D}$, in 96 well plates containing nutrient rich and nutrient poor broth media. As a result, 7 representative isolates were obtained. It was interesting to see that all isolates obtained from method D took part in the representatives. Also, the $35 \%$ of the 20 representative isolates were obtained from the method D (Table 4).

The abundance of Streptomyces genera was reported previously [3] [21] [22] [34]. Culture-dependent and culture-independent methods for sponge-associated Streptomyces from Haliclona sp. have shown that the members of Streptomyces were dominant [34]. Similarly, over $80 \%$ of the isolates from Iotrochota sp. belonged to Streptomyces genus [21]. The most abundant genus was reported as Streptomyces which represent $74 \%$ of the isolates from Hymeniacidon perleve collected from the Yellow Sea, China [3], whereas the genus Streptomyces 
Table 3. Viable counts of actinomycetes from different sponge species after plating onto agar media.

\begin{tabular}{ccccccccccc}
\hline \multirow{2}{*}{ Sponge codes } & \multicolumn{9}{c}{$\mathrm{A}^{\mathrm{a}}$} & \multicolumn{2}{c}{$\mathrm{B}$} & \multicolumn{2}{c}{$\mathrm{C}$} \\
\cline { 2 - 9 } & $\mathrm{M} 1^{\mathrm{b}}$ & $\mathrm{M} 6$ & $\mathrm{AIA}$ & $\mathrm{R} 2 \mathrm{~A}$ & $\mathrm{SE}$ & $\mathrm{AW}$ & $\mathrm{ISP} 4$ & $\mathrm{R} 2 \mathrm{~A}$ & $\mathrm{M} 1$ \\
$8-1$ & $3.7 .10^{4}$ & $6.3 .10^{4}$ & $7.10^{3}$ & $2.10^{4}$ & $<10^{2}$ & $\mathrm{ND}$ & $\mathrm{ND}$ & $5.6 .10^{4}$ & $1.7 .10^{5}$ \\
$8-3$ & $4.10^{4}$ & $5.2 .10^{4}$ & $<10^{3}$ & $4.10^{4}$ & $\mathrm{ND}$ & $\mathrm{ND}$ & $<10^{3}$ & $1.10^{5}$ & $9.7 .10^{4}$ \\
$8-4$ & $<10^{3}$ & $<10^{3}$ & $<10^{3}$ & $<10^{3}$ & $<10^{2}$ & $\mathrm{ND}$ & $\mathrm{ND}$ & $6.10^{4}$ & $4.5 .10^{4}$ \\
$8-5$ & $<10^{3}$ & $1.10^{5}$ & $4.10^{4}$ & $5.6 .10^{4}$ & $\mathrm{ND}$ & $\mathrm{ND}$ & $\mathrm{ND}$ & $4.10^{4}$ & $4.10^{4}$ \\
$8-6$ & $<10^{3}$ & $\mathrm{ND}$ & $\mathrm{ND}$ & $\mathrm{ND}$ & $\mathrm{ND}$ & $\mathrm{ND}$ & $\mathrm{ND}$ & $\mathrm{ND}$ & $<10^{3}$ \\
$8-7$ & $<10^{3}$ & $<10^{3}$ & $<10^{3}$ & $<10^{3}$ & $\mathrm{ND}$ & $\mathrm{ND}$ & $<10^{3}$ & $<10^{3}$ & $<10^{3}$ \\
$8-8$ & $2.10^{5}$ & $<10^{3}$ & $1.7 .10^{5}$ & $5.8 .10^{4}$ & $\mathrm{ND}$ & $\mathrm{ND}$ & $\mathrm{ND}$ & $1.3 .10^{5}$ & $1.1 .10^{5}$ \\
$9-1$ & $2.4 .10^{5}$ & $<10^{3}$ & $8.10^{4}$ & $3.10^{4}$ & $<10^{2}$ & $\mathrm{ND}$ & $<10^{3}$ & $<10^{3}$ & $<10^{3}$ \\
$9-2$ & $5.6 .10^{4}$ & $<10^{3}$ & $<10^{3}$ & $\mathrm{ND}$ & $<10^{2}$ & $\mathrm{ND}$ & $\mathrm{ND}$ & $\mathrm{ND}$ & $<10^{3}$ \\
$9-3$ & $5.10^{4}$ & $<10^{3}$ & $1.5 .10^{5}$ & $<10^{3}$ & $\mathrm{ND}$ & $\mathrm{ND}$ & $\mathrm{ND}$ & $<10^{3}$ & $<10^{3}$ \\
$9-4$ & $\mathrm{ND}$ & $\mathrm{ND}$ & $\mathrm{ND}$ & $\mathrm{ND}$ & $<10^{2}$ & $\mathrm{ND}$ & $\mathrm{ND}$ & $\mathrm{ND}$ & $\mathrm{ND}$ \\
$9-5$ & $\mathrm{ND}$ & $\mathrm{ND}$ & $\mathrm{ND}$ & $\mathrm{ND}$ & $\mathrm{ND}$ & $\mathrm{ND}$ & $\mathrm{ND}$ & $\mathrm{ND}$ & $\mathrm{ND}$ \\
$9-6$ & $9.10^{4}$ & $1.10^{5}$ & $1.1 .10^{5}$ & $6.7 .10^{4}$ & $<10^{2}$ & $\mathrm{ND}$ & $\mathrm{ND}$ & $>3.10^{5}$ & $2.4 .10^{5}$ \\
$10-1$ & $\mathrm{ND}$ & $<10^{3}$ & $\mathrm{ND}$ & $\mathrm{ND}$ & $\mathrm{ND}$ & $\mathrm{ND}$ & $\mathrm{ND}$ & $<10^{3}$ & $<10^{3}$ \\
$10-2$ & $<10^{3}$ & $<10^{3}$ & $<10^{3}$ & $<10^{3}$ & $<10^{2}$ & $\mathrm{ND}$ & $<10^{3}$ & $<10^{3}$ & $<10^{3}$ \\
\hline
\end{tabular}

${ }^{\mathrm{a}}$ Pre-treatment methods; ${ }^{\mathrm{b}}$ Media; ND: not determined.

Table 4. Culturable sponge-associated actinomycetes, their antimicrobial activities and seawater requirement.

\begin{tabular}{|c|c|c|c|c|c|c|c|c|c|c|}
\hline \multirow{2}{*}{ Isolate codes } & \multirow{2}{*}{$\begin{array}{l}\text { Sponge } \\
\text { codes }\end{array}$} & \multirow{2}{*}{$\begin{array}{l}\text { Isolation } \\
\text { method }\end{array}$} & \multirow{2}{*}{ Medium } & EC & MRSA & VREF & PA & CA & Sw & Dw \\
\hline & & & & \multicolumn{5}{|c|}{ Inhibition zone diameter (mm) } & \multicolumn{2}{|c|}{ Growth } \\
\hline 8SM017 & $8-3$ & A & M6 & - & - & - & - & 25 & +++ & +++ \\
\hline 8SM026 & $8-4$ & A & $\mathrm{R} 2 \mathrm{~A}$ & - & 17 & 14 & - & - & +++ & - \\
\hline $8 \mathrm{SM} 027$ & $8-4$ & $\mathrm{D}$ & $\mathrm{R} 2 \mathrm{~A}$ & - & - & - & - & - & +++ & ++ \\
\hline 8SM031 & $8-5$ & $\mathrm{D}$ & M1 & - & - & - & - & - & +++ & ++ \\
\hline 8SM032 & $8-5$ & $\mathrm{D}$ & $\mathrm{R} 2 \mathrm{~A}$ & - & 9 & - & - & - & +++ & ++ \\
\hline 8SM034 & $8-5$ & $\mathrm{D}$ & SMP & - & - & - & - & - & +++ & ++ \\
\hline 8SM036 & $8-6$ & A & M6 & - & 9 & - & - & 15 & +++ & + \\
\hline 8SM039 & $8-6$ & B & ISP4 & - & - & - & - & - & +++ & +++ \\
\hline 8SM040 & 8-6 & B & ISP4 & - & 11 & - & - & - & - & - \\
\hline 8SM043 & $8-7$ & A & M6 & - & 12 & - & - & 12 & +++ & + \\
\hline 8SM044 & $8-7$ & B & ISP4 & - & 9 & - & - & - & +++ & +++ \\
\hline 8SM048 & $8-8$ & B & ISP4 & - & 9 & - & - & - & +++ & +++ \\
\hline 8SM050 & $8-8$ & $\mathrm{C}$ & M1 & - & 11 & - & - & - & +++ & +++ \\
\hline 9SM003 & $9-1$ & A & M1 & - & 8 & - & - & - & +++ & +++ \\
\hline 9SM010 & $9-1$ & $\mathrm{D}$ & $\mathrm{R} 2 \mathrm{~A}$ & - & - & 11 & - & - & +++ & + \\
\hline 9SM013 & $9-2$ & A & AIA & - & 9 & - & - & - & - & - \\
\hline 9SM015 & $9-3$ & $\mathrm{D}$ & SMP & - & 11 & 13 & - & - & ++ & + \\
\hline 9SM016 & $9-5$ & A & M1 & - & 10 & - & - & - & +++ & - \\
\hline 9SM023 & $9-5$ & $\mathrm{D}$ & M1 & - & - & - & - & - & +++ & - \\
\hline 10SM012 & $10-2$ & B & ISP4 & - & 10 & 10 & - & - & +++ & + \\
\hline
\end{tabular}

EC; E. coli, MRSA; methicillin resistant S. aureus, VREF; vancomycin resistant E. faecium, PA; P.aeruginosa, CA; C. albicans, Sw; seawater, Dw; distilled water, -: no, +: weak, ++: moderate, +++: good. 
from the same sponge collected from South China Sea was reported as a minor group from both culture-dependent and culture-independent studies [35]. These results are in accordance with our findings; Streptomyces appears to be the dominant genus of the sponge-associated Actinobacteria from sponges collected from Eastern Mediterranean Sea.

The production of antibiotic and other secondary metabolites provides a selective advantage when in competition with other organisms. Actinobacteria are well-known antibiotic producers that establish symbiotic interaction with sponge hosts [36]. However, the antimicrobial activity of the isolates including Nocardiopsis strains was unstable. An activity loss was encountered after two or three follow up transfers of the strains to new media. Accordingly, activity loss of sponge-associated bacteria was reported previously by Muscholl-Silberhorn et al. (2007) [37]. On the other hand, high level activity loss observed for sponge-associated isolates was not the case for our sediment isolates previously [38]. A comprehensive literature search has not revealed any clue for this phenomenon. Detailed studies should be performed to shed light on this issue.

Consequently, in the current study, all of the isolates have not shown an absolute requirement for seawater onto agar plates as reported previously [3] [17] [20] [33], while the existence of seawater in favour of actinobacteria. It was reported that some actinomycetes isolates grew better in distilled water [39]; however, we did not observe a clear positive effect for growth and sporulation on medium containing distilled water.

\section{Acknowledgements}

This study was supported by Scientific and Technological Research Council of Turkey (TUBITAK) with SBAG-109S361project number.

\section{References}

[1] Fieseler, L., Horn, M., Wagner, M. and Hentschel, U. (2004) Discovery of the Novel Candidate Phylum "Poribacteria” in Marine Sponges. Applied and Environmental Microbiology, 70, 3724-3732. http://dx.doi.org/10.1128/AEM.70.6.3724-3732.2004

[2] Taylor, M.W., Radax, R., Steger, D. and Wagner, M. (2007) Sponge-Associated Microorganisms: Evolution, Ecology, and Biotechnological Potential. Microbiology and Molecular Biology Reviews, 71, 295-347. http://dx.doi.org/10.1128/MMBR.00040-06

[3] Zhang, H., Lee, Y.K., Zhang, W. and Lee, H.K. (2006) Culturable Actinobacteria from the Marine Sponge Hymeniacidonperleve: Isolation and Phylogenetic Diversity by 16S rRNA Gene-RFLP Analysis. Antonie van Leeuwenhoek, 90, 159-169. http://dx.doi.org/10.1007/s10482-006-9070-1

[4] Proksch, P. (1994) Defensive Roles for Secondary Metabolites from Marine Sponges and Sponge-Feeding Nudibranchs. Toxicon, 32, 639-655. http://dx.doi.org/10.1016/0041-0101(94)90334-4

[5] Thakur, N.L. and Müller, W.E.G. (2004) Biotechnological Potential of Marine Sponges. Current Science, 86, 15061512.

[6] Oclarit, J.M., Okada, H., Ohta, S., Kaminura, K., Yamaoka, Y., Iizuka, T., Miyashiro, S. and Ikegami, S. (1994) AntiBacillus Substance in the Marine Sponge, Hyatella Species, Produced by an Associated Vibrio Species Bacterium. Microbios, 78, 7-16.

[7] Jayatilake, G.S., Thornton, M.P., Leonard, A.C., Grimwade, J.E. and Baker, B.J. (1996) Metabolites from an Antarctic Sponge Associated Bacterium, Pseudomonas aeruginosa. Journal of Natural Products, 59, 293-296. http://dx.doi.org/10.1021/np960095b

[8] Piel, J., Hui, D., Wen, G., Butzke, D., Platzer, M., Fusetani, N. and Matsunaga, S. (2004) Antitumor Polyketide Biosynthesis by an Uncultivated Bacterial Symbiont of the Marine Sponge Theonellaswinhoei. Proceedings of the National Academy of Sciences, 101, 16222-16227. http://dx.doi.org/10.1073/pnas.0405976101

[9] Montalvo, N.F., Mohamed, N.M., Enticknap, J.J. and Hill, R.T. (2005) Novel Actinobacteria from Marine Sponges. Antonie van Leeuwenhoek, 87, 29-36. http://dx.doi.org/10.1007/s10482-004-6536-X

[10] Webster, N.S., Wilson, K.J., Blackall, L.L. and Hill, R.T. (2001) Phylogenetic Diversity of Bacteria Associated with the Marine Sponge Rhopaloeidesodorabile. Applied and Environmental Microbiology, 67, 434-444. http://dx.doi.org/10.1128/AEM.67.1.434-444.2001

[11] Hentschel, U., Hopke, J., Horn, M., Friedrich, A.B., Wagner, M., Hacker, J. and Moore, B.S. (2002) Molecular Evidence for a Uniform Microbial Community in Sponges from Different Oceans. Applied and Environmental Microbiology, 68, 4431-4440. http://dx.doi.org/10.1128/AEM.68.9.4431-4440.2002

[12] Kamke, J., Taylor, M.W. and Schmitt, S. (2010) Activity Profiles for Marine Sponge-Associated Bacteria Obtained by 
16S rRNA vs 16S rRNA Gene Comparisons. The ISME Journal, 4, 498-508. http://dx.doi.org/10.1038/ismej.2009.143

[13] Webster, N.S., Taylor, M.W., Behnam, F., Lücker, S., Rattei, T., Whalan, S., Horn, M. and Wagner, M. (2010) Deep Sequencing Reveals Exceptional Diversity and Modes of Transmission for Bacterial Sponge Symbionts. Environmental Microbiology, 2, 2070-2082.

[14] Myadoh, S. (1993) Research on Antibiotic Screening in Japan over the Last Decade: A Producing Microorganism Approach. Actinomycetologica, 7, 100-106. http://dx.doi.org/10.3209/saj.7_100

[15] Kampfer, P. (2006) The Family Streptomycetaceae, Part I: Taxonomy. In: Dworkin, M., Falkow, S., Rosenberg, E., Schleifer, K.-H. and Stackebrandt, E., Eds., The Prokaryotes, 3rd Edition, Springer Science + Business Media, LLC, New York, 538-604.

[16] Moran, M.A., Rutherford, L.T. and Hodson, R.E. (1995) Evidence for Indigenous Streptomyces Populations in a Marine Environment Determined with a 16S rRNA Probe. Applied and Environmental Microbiology, 61, 3695-3700.

[17] Mincer, T.J., Jensen, P.R., Kauffman, C.A. and Fenical, W. (2002) Widespread and Persistent Populations of a Major New Marine Actinomycete Taxon in Ocean Sediments. Applied and Environmental Microbiology, 68, 5005-5011. http://dx.doi.org/10.1128/AEM.68.10.5005-5011.2002

[18] Kim, T.K., Garson, M.J. and Fuerst, J.A. (2005) Marine Actinomycetes Related to the "Salinispora" Group from the Great Barrier Reef Sponge Pseudoceratina clavata. Environmental Microbiology, 7, 509-518. http://dx.doi.org/10.1111/j.1462-2920.2005.00716.X

[19] Li, Z.Y. and Liu, Y. (2006) Marine Sponge Craniella austrialiensis-Associated Bacterial Diversity Revelation Based on 16S rDNA Library and Biologically Active Actinomycetes Screening, Phylogenetic Analysis. Letters in Applied Microbiology, 43, 410-416. http://dx.doi.org/10.1111/j.1472-765X.2006.01976.x

[20] Jiang, S., Sun, W., Chen, M., Dai, S., Zhang, L., Liu, Y., Lee, K.J. and Li, X. (2007) Diversity of Culturable Actinobacteria Isolated from Marine Sponge Haliclona sp. Antonie van Leeuwenhoek, 92, 405-416. http://dx.doi.org/10.1007/s10482-007-9169-z

[21] Jiang, S., Li, X., Zhang, L., Sun, W., Dai, S., Xie, L., Liu, Y. and Lee, K.J. (2008) Culturable Actinobacteria Isolated from Marine Sponge Iotrochota sp. Marine Biology, 153, 945-952. http://dx.doi.org/10.1007/s00227-007-0866-y

[22] Schneemann, I., Ohlendorf, B., Zinecker, H., Nagel, K., Wiese, J. and Imhoff, J.F. (2010) Nocapyrones A-D, GammaPyrones from a Nocardiopsis Strain Isolated from the Marine Sponge Halichondria panicea. Journal of Natural Products, 73, 1444-1447. http://dx.doi.org/10.1021/np100312f

[23] Zhang, H., Zhang, W., Jin, Y., Jin, M. and Yu, X. (2008) A Comparative Study on the Phylogenetic Diversity of Culturable Actinobacteria Isolated from Five Marine Sponge Species. Antonie van Leeuwenhoek, 93, 241-248. http://dx.doi.org/10.1007/s10482-007-9196-9

[24] Selvin, J., Shanmughapriya, S., Gandhimathi, R., Kiran, G.S., Ravji, T.R., Natarajaseenivasan, K. and Hema, T.A. (2009) Optimization and Production of Novel Antimicrobial Agents from Sponge Associated Marine Actinomycetes Nocardiopsis dassonvillei MAD08. Applied Microbiology and Biotechnology, 83, 435-445. http://dx.doi.org/10.1007/s00253-009-1878-y

[25] Abdelmohsen, U.R., Pimente-Elardo, S.M., Hanora, A., Radwan, M., Abou-El-Ela, S.H., Ahmed, S. and Hentschel, U. (2010) Isolation, Phylogenetic Analysis and Anti-Infective Activity Screening of Marine Sponge-Associated Actinomycetes. Marine Drugs, 8, 399-412. http://dx.doi.org/10.3390/md8030399

[26] Jensen, P.R., Gontang, E., Mafnas, C., Mincer, T.J. and Fenical, W. (2005) Culturable Marine Actinomycete Diversity from Tropical Pacific Ocean Sediments. Environmental Microbiology, 7, 1039-1048. http://dx.doi.org/10.1111/j.1462-2920.2005.00785.x

[27] Connon, S.A. and Giovannoni, S.J. (2002) High-Throughput Methods for Culturing Microorganisms in Very-Low-Nutrient Media Yield Diverse New Marine Isolates. Applied and Environmental Microbiology, 68, 3878-3885.

http://dx.doi.org/10.1128/AEM.68.8.3878-3885.2002

[28] CLSI (Clinical and Laboratory Standards) (2007) Performance Standards for Antimicrobial Susceptibility Testing, 17th Informational Supplement. M100-S17, Vol. 27, CLSI.

[29] Liu, D., Coloe, S., Baird, R. and Pedersen, J. (2000) Rapid Mini-Preparation of Fungal DNA for PCR. Journal of Clinical Microbiology, 38, 471.

[30] Hameş-Kocabaş, E.E. and Uzel, A. (2012) Isolation Strategies of Marine-Derived Actinomycetes from Sponge and Sediment Samples. Journal of Microbiological Methods, 88, 342-347. http://dx.doi.org/10.1016/j.mimet.2012.01.010

[31] Jensen, P.R., Dwight, R. and Fenical. W. (1991) Distribution of Actinomycetes in Near-Shore Tropical Marine Sediments. Applied and Environmental Microbiology, 57, 1102-1108.

[32] Kroppenstedt, R.M. and Evtushenko, L.I. (2006) The Family Nocardiopsaceae. In: Dworkin, M., Falkow, S., Rosenberg, E., Schleifer, K.H. and Stackebrandt, E., Eds, The Prokaryotes, 3rd Edition, Springer Science+Business Media, 
LLC, New York, 754-795.

[33] Maldonado, L.A., Stach, J.E.M., Pathom-aree, W., Ward, A.C., Bull, A.T. and Goodfellow, M. (2005) Diversity of Cultivable Actinobacteria in Geographically Widespread Marine Sediments. Antonie van Leeuwenhoek, 87, 11-18. http://dx.doi.org/10.1007/s10482-004-6525-0

[34] Khan, S.T., Komaki, H., Motohashi, K., Kozone, I., Mukai, A., Takagi, M, and Shin-ya, K. (2011) Streptomyces Associated with a Marine Sponge Haliclona sp.; Biosynthetic Genes for Secondary Metabolites and Products. Environmental Microbiology, 13, 391-403. http://dx.doi.org/10.1111/j.1462-2920.2010.02337.x

[35] Sun, W., Dai, S., Jiang, S., Wang, G., Liu, G., Wu, H. and Li, X. (2010) Culture-Dependent and Culture-Independent Diversity of Actinobacteria Associated with the Marine Sponge Hymeniacidon perleve from the South China Sea. Antonie van Leeuwenhoek, 98, 65-75. http://dx.doi.org/10.1007/s10482-010-9430-8

[36] Hentschel, U., Schmid, M., Wagner, M., Fieseler, L., Gernert, C. and Hacker, J. (2001) Isolation and Phylogenetic Analysis of Bacteria with Antimicrobial Activities from the Mediterranean Sponges Aplysina aerophoba and Aplysina cavernicola. FEMS Microbiology Ecology, 35, 305-312. http://dx.doi.org/10.1111/j.1574-6941.2001.tb00816.x

[37] Muscholl-Silberhorn, A., Thiel, V. and Imhoff, J.F. (2007) Abundance and Bioactivity of Cultured Sponge-Associated Bacteria from the Mediterranean Sea. Microbial Ecology, 55, 94-106. http://dx.doi.org/10.1007/s00248-007-9255-9

[38] Ozcan, K., Aksoy, S.Ç., Kalkan, O., Uzel, A., Hames-Kocabas, E.E. and Bedir, E. (2013) Diversity and Antibiotic Producing Potentials of Cultivable Marine-Derived Actinomycetes from Coastal Sediments of Turkey. Journal of Soils and Sediments, 13, 1493-1501. http://dx.doi.org/10.1007/s00248-007-9255-9

[39] Bredholt, H., Fjærvik, E., Johnsen, G. and Zotchev, S.B. (2008) Actinomycetes from Sediments in the Trondheim Fjord, Norway: Diversity and Biological Activity. Marine Drugs, 6, 12-24. http://dx.doi.org/10.3390/md6010012

[40] Gontang, E.A., Fenical, W. and Jensen, P.R. (2007) Phylogenetic Diversity of Gram-Positive Bacteria Cultured from Marine Sediments. Applied and Environmental Microbiology, 73, 3272-3282. http://dx.doi.org/10.1128/AEM.02811-06

[41] Imada, C., Masuda, S., Kobayashi, T., Hamada-Sato, N. and Nakashima, T. (2010) Isolation and Characterization of Marine and Terrestrial Actinomycetes Using a Medium Supplemented with NaCl. Actinomycetologica, 24, 12-17. http://dx.doi.org/10.3209/saj.SAJ240104

\section{Abbreviation List}

$\begin{array}{ll}\text { ACTINOCC } & \text { Actinomycetes Culture Collection } \\ \text { AIA } & \text { Actinomycete Isolation Agar } \\ \text { AW } & \text { Water Agar } \\ \text { BLAST } & \text { Basic Local Alignment Search Tool } \\ \text { CLSI } & \text { Clinical and Laboratory Standards } \\ \text { DAPI } & \text { 4',6-diamidino-2-phenylindole } \\ \text { ISP4 } & \text { International Streptomyces Project 4 } \\ \text { MHA } & \text { Mueller Hinton Agar } \\ \text { MRSA } & \text { Methicillin-Resistant Staphylococcus aureus } \\ \text { NCBI } & \text { National Center for Biotechnology Information } \\ \text { PCR } & \text { Polymerase Chain Reaction } \\ \text { R2A } & \text { Reasoner's 2A Agar } \\ \text { SDA } & \text { Saboraud Dextrose Agar } \\ \text { SE } & \text { Sponge Extract Agar } \\ \text { SMP } & \text { Sponge Mannitol Peptone } \\ \text { TLC } & \text { Thin Layer Chromatography } \\ \text { UV } & \text { Ultraviolet } \\ \text { VREF } & \text { Vancomycin-Resistant Enterococcus faecium }\end{array}$

